\title{
Łódzka stomatologia w okresie I wojny światowej (1914-1918)
}

\section{Summary}

\section{Dentistry in Łódź during the First World War}

The issue of care for oral health was undoubtedly not the most important medical agendas during World War I. There is not much information on this subject preserved even from archival materials. The health service in Łódź was much more focused, for example, on the fight against infectious diseases, which is why few people had access to dentists. The dental offices were visited almost exclusively by wealthy people.

Keywords: Łódź 1914-1918, history of dentistry

\section{Streszczenie}

Zagadnienie dbałości o zdrowie jamy ustnej niewątpliwie nie należało do najważniejszych programów medycznych w czasie pierwszej wojny światowej. Niewiele zachowało się na ten temat informacji nawet $\mathrm{w}$ materiałach archiwalnych. Służba zdrowia w Łodzi była dużo bardziej nastawiona np. na walkę z chorobami zakaźnymi, dlatego niewielu ludzi miało dostęp do dentystów. Gabinety odwiedzały prawie wyłącznie osoby zamożne.

Słowa kluczowe: Łódź 1914-1918, historia stomatologii

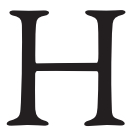
igiena jamy ustnej należała do najbardziej zaniedbanych zagadnień zdrowotnych łodzian w początkach XX w. Analizując archiwalia dotyczące łódzkiej medycyny z czasów Wielkiej Wojny, trudno znaleźć szersze informacje na temat organizacji opieki medycznej tejże specjalności. Można wysunąć tezę, że ówczesne władze przykładały zdecydowanie więcej uwagi do np. walki z chorobami zakaźnymi, 
będącymi najczęstszymi przyczynami zgonów ówczesnych łodzian ${ }^{1}$. Kwestie związane ze zdrowiem uzębienia schodziły w tamtym czasie zdecydowanie na drugi, a nawet na trzeci plan. Także sami łodzianie, którzy na co dzień nie zawsze przestrzegali podstawowych zasad higieny, zapewne nie wykazywali większej troski w stosunku do swego uzębienia ${ }^{2}$.

Z dokumentacji służb miejskich odpowiedzialnych za opiekę zdrowotną łodzian w czasie Wielkiej Wojny niewiele można się dowiedzieć o opiece stomatologicznej³ $\mathrm{Na}$ terenie miasta istniało zaledwie kilka ogólnodostępnych punktów, w których mieszkańcy miasta mogli leczyć zęby.

Większa dbałość o zdrowie uzębienia łodzian nie miała charakteru stałego, a wiązała się zwykle z poszczególnymi akcjami inicjowanymi przez instytucje medyczne bądź organizacje społeczne. Dbałość o higienę jamy ustnej wprowadzały sporadycznie niektóre szpitale. Wzmianki o wyposażeniu pacjentów w szczoteczki do zębów znajdujemy chociażby w sprawozdaniu z działalności szpitala dla lekko gruźliczych w podłódzkich Chojnach $^{4}$. Na opiekę stomatologiczną w okrojonym zapewne zakresie mogły liczyć dzieci pozostające pod opieką miejscowych organizacji dobroczynnych. Podopiecznymi Łódzkiego Żydowskiego Towarzystwa Opieki nad Sierotami zajmowały się następujące dentystki: J. Karmazyn, F. Goldbergowa i Elefantowa5.

Problem próchnicy dotyczył w dużym stopniu łódzkich dzieci. W 1918 r. stomatolog Michał Salzwasser wystosował do władz miasta memoriał, w którym podkreślał, że próchnica jest chorobą społeczną. W piśmie wspominał o tym, że pracował honorowo jako lekarz dentysta w szkole przy Pl. Kościelnym od grudnia 1917 r. do czerwca 1918 r. Proponował, by gabinetowi dentystycznemu przy ul. Krótkiej (ob. Traugutta) 5 nadać nazwę „Pierwszej lecznicy zębów i jamy ustnej dla dzieci szkół ludowych miejskich", a także wnioskował, aby przeprowadzać stosowne pogadanki o higienie jamy ustnej w szkołach ${ }^{6}$. W 1918 r. Miejscowa Rada Opiekuńcza, biorąc pod uwagę zły stan uzębienia najmłodszych łodzian przebywających w ochronkach i schroniskach,

Szerzej na temat problemu: J. Fijałek, J. Supady, Gruźlica ptuc Łodzi od schytku XIX do 1918 r.Z dziejów walki z choroba, Łódź 2002, s. 28; A. Kulesza, Zapobieganie i zwalczanie chorób zakaźnych w Eodzi w latach 1915-1918 w swietle regulacji normatywnych niemieckich cywilnych wtadz okupacyjnych, „Studia z Dziejów Państwa i Prawa Polskiego” 2007, t. X, s. 249-264; A. Margolis, Gruźlica w Eodzi. Studium epidemiologiczno-statystyczne, Łódź 1932, s. 3; A. Stawiszyńska, Łódź w latach I wojny światowej, Oświęcim 2016, s. 314-319; J. Supady, Walka z cholera w Eodzi na przetomie XIX i XX wieku, „Polski Tygodnik Lekarski” 1978, t. XXXIII, nr 2, s. 75-76.

2 Szerzej na temat higieny panującej w mieście: A. Stawiszyńska, op. cit., s. 291-310.

3 Podczas kwerendy dotyczącej dziejów miasta w latach 1914-1918 z zagadnieniem opieki dentystycznej spotkałam się sporadycznie.

4 M. Pawłowska-Dąbrowska, Sprawozdanie z czynności szpitala miejskiego dla lekko-gruźliczych w Chojnach pod Łodzia za lata 1916-1917, „Zdrowie. Organ Warszawskiego Towarzystwa Higienicznego” 1918 , t. VII, s. 5.

5 J. Sosnowska, Opieka nad dziećmi w Łodzi w latach I wojny światowej, Łódź 2017, s. 380.

6 Memoriał M. Salzwassera do Rady Miejskiej, Archiwum Państwowe w Łodzi [dalej: APŁ], Akta miasta Łodzi [dalej: AmŁ], Wydział Prezydialny, sygn. 13 515, k. 131-134. 
zadecydowała o ich badaniu i leczeniu, począwszy od września. Nad realizacją planu miała czuwać specjalna komisja lekarska7. W listopadzie 1918 r. Rada Miejska wydała dezyderat, w którym zapowiadała wprowadzenie bezpłatnej pomocy lekarskiej i dentystycznej dla uczniów ${ }^{8}$. Przy Wydziale Szkolnictwa postanowiono powołać Komisję do Spraw Zorganizowania Pomocy Dentystycznej dla Dzieci Szkół Miejskich. W związku z tym wysunięto projekt powiększenia budżetu Wydziału Szkolnictwa o $1 \mathrm{mkp}$ na każde dziecko'.

Zamożniejsi łodzianie z problemami stomatologicznymi leczyli się głównie w prywatnych gabinetach, o których działalności wspominają chociażby anonse prasowe. Zdecydowana większość prywatnych gabinetów stomatologicznych zlokalizowana była w centrum miasta, tj. na ul. Piotrkowskiej i jej najbliższej okolicy. W kwietniu 1918 r. z rozporządzenia Ministerstwa Zdrowia rozpoczęto rejestrację miejscowych dentystów oraz techników. Niezarejestrowani mieli się zgłaszać do siedziby lekarza powiatowego przy ul. Piotrkowskiej $87^{10}$.

Tabela

Adresy wybranych prywatnych gabinetów dentystycznych

\begin{tabular}{|l|l|}
\hline \multicolumn{1}{|c|}{ Imię i nazwisko } & \multicolumn{1}{c|}{ Adres } \\
\hline Gustaw Klukow jr & Piotrkowska 3 (Hotel Polski) \\
\hline R. Szapiro & Długa 11 (ob. Gdańska) \\
\hline Maria Libera & Sienkiewicza 53 \\
\hline H. Lewitówna & Piotrkowska 17 \\
\hline F. Czlenow & Piotrkowska 200 \\
\hline H. Konowa & Rozwadowska 6 \\
\hline S. Gordin & Konstantynowska 18 (ob. Legionów) \\
\hline S. Goldman & Milsza (ob. Kopernika) 9 \\
\hline Feliks Seidengart & Zawadzka 8 (ob. Próchnika) \\
\hline R. Epsztein & Główna 41 \\
\hline
\end{tabular}

„Godzina Polski” [dalej: GP], 6 VIII 1918, nr 213, s. 6.

Dezyderaty z dn. 22 XI 1917 r., APE, AmE, Rada Miejska, sygn. 12 109, k. 8-9.

„Nowy Kurier Łódzki” [dalej: NKE], 11 X 1918, nr 279, s. 2.

10 GP, 2 IV 1918, nr 90, s. 6; 24 IV, nr 111, s. 6. 
Tabela (cd.)

\begin{tabular}{|l|l|}
\hline \multicolumn{1}{|c|}{ Imię i nazwisko } & \multicolumn{1}{c|}{ Adres } \\
\hline J. Halpern & Piotrkowska 18 \\
\hline E. Fuchs & Benedykta 2 \\
\hline D. Sperling & Zawadzka 23 \\
\hline P. Żytnicka & Konstantynowska 9 \\
\hline A. Teplitzki & Piotrkowska 121 \\
\hline B. Sładkin & Piotrkowska 88 \\
\hline E. Wołkowicz & Średnia 3 (później 11) (ob. Pomorska) \\
\hline M. Długacz-Kaniewska & Zawadzka 6 (ob. Próchnika) \\
\hline S. Dąbrowski & Rozwadowska 1 \\
\hline $\begin{array}{l}\text { Pierwsza Chrześcijańska Lecznica } \\
\text { Chorób Zębów i Jamy Ustnej }\end{array}$ & Mikołajewska (ob. Sienkiewicza) 83 \\
\hline
\end{tabular}

Ź r ó d ł o: oprac. własne na podstawie anonsów prasowych.

Wspomniane anonse są nielicznymi źródłami do dziejów łódzkiej stomatologii. Dentyści łódzcy, zamieszczając anonse prasowe, chętnie podkreślali swoje doświadczenie zawodowe, zwłaszcza staże u autorytetów w tejże dziedzinie. Sperling podkreślał, że był asystentem prof. Moellera w Berlinie ${ }^{11}$. Fuchs zaznaczał, że był wieloletnim asystentem w gabinecie nadwornego stomatologa, prof. Engla w Berlinie, a także pracował w Londynie, Nowym Jorku i Filadelfii ${ }^{12}$. Helena Konowa wspominała o długoletniej współpracy z drem Rittem ${ }^{13}$. Rena Rozenman szczyciła się, że niegdyś była asystentką J. Haberfelda ${ }^{14}$. Goldman podkreślał, że był asystentem dra Żadewicza ${ }^{15}$.

Nieliczne reklamy wspominały o metodach leczniczych stosowanych w poszczególnych gabinetach. W 1915 r. anons D. Sperlinga zawiadamiat, że dentysta stosuje leczenie elektrycznością oraz masażem ${ }^{16}$. Pacjenci R. Epszteina mogli liczyć na „wyjmowanie zębów przy użyciu specjalnego aparatu" ${ }^{17}$. Lewita obiecywała usuwanie

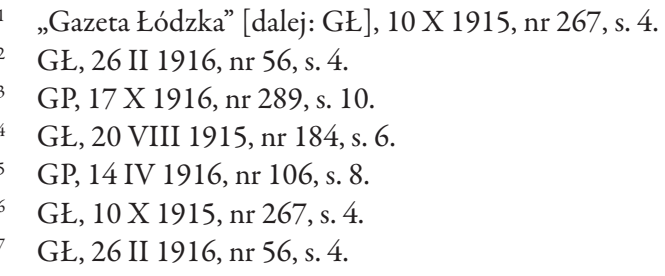


zębów bez bólu ${ }^{18}$. Chwat oferował umacnianie ruszających się zębów, regulowanie krzywoszczęku i wystających szczek, a także masaż wibracyjny przy zapaleniu dziąseł oraz „uzupełnianie brakujących części twarzy”. W anonsach podkreślał, że stosuje najnowsze wynalazki według dra Aryapaca i prof. Junga ${ }^{19}$. W Pierwszej Chrześcijańskiej Lecznicy Chorób Zębów i Jamy Ustnej stosowano natomiast leczenie homeopatycz$n^{20}$. Wiele gabinetów oferowało możliwość zaopatrzenia się w sztuczne szczęki. Niektóre anonse oferowały owe protezy na preferencyjnych warunkach, tak by pozyskać kolejnych klientów („sztuczne zęby w celu reklamy bardzo tanio albo też bezpłatnie u dentysty") ${ }^{21}$. Niektóre łódzkie gabinety, np. R. Epsteina czy Marii Długacz-Kaniewskiej, oferowały złote korony czy plomby ze wspomnianego kruszcu oraz porcelany ${ }^{22}$.

Usługi dentystyczne, podobnie jak wiele innych, ulegały rozmaitym modom. Przykładowo jesienią 1917 r. notowano wzmożone zainteresowanie zakładaniem złotych koron u bogacących się warstw społecznych ${ }^{23}$.

Niektórzy stomatolodzy poszukiwali poprzez ogłoszenia prasowe pracowników. W styczniu 1916 r. na łamach „Gazety Łódzkiej” ukazał się anons głoszący, że w gabinecie przy ul. Piotrkowskiej 35 był „potrzebny lokaj lub chłopiec do 18 lat do posług do dentysty"24.

Reklamy prasowe informowały tódzkich pacjentów o powrotach, zwłaszcza tych w 1918 r., gdy do miasta masowo powracały osoby, które zmuszone były z różnych powodów opuścić Łódź w związku z wybuchem wojny ${ }^{25}$, lub np. po wakacyjnych wyjazdach ${ }^{26}$.

Reklamy prasowe zamieszczane przez łódzkich dentystów dotyczyły nie tylko reklamowania własnej działalności czy poszukiwania pracowników. Wiosną $1918 \mathrm{r}$. na łamach "Godziny Polski” pojawiał się anons trzydziestoletniego lekarza dentysty, wyznania mojżeszowego, który poszukiwał żony. Od kandydatek wymagał majątku w wysokości minimum 40 tys. mkp, a także przesłania fotografii ${ }^{27}$. Niekiedy w prasie pojawiały się anonse dotyczące poszukiwań asystentów stomatologicznych lub „uczniów do robót technicznych"28. Wspominały też one o wolnych i urządzonych gabinetach do wynajęcia ${ }^{29}$.

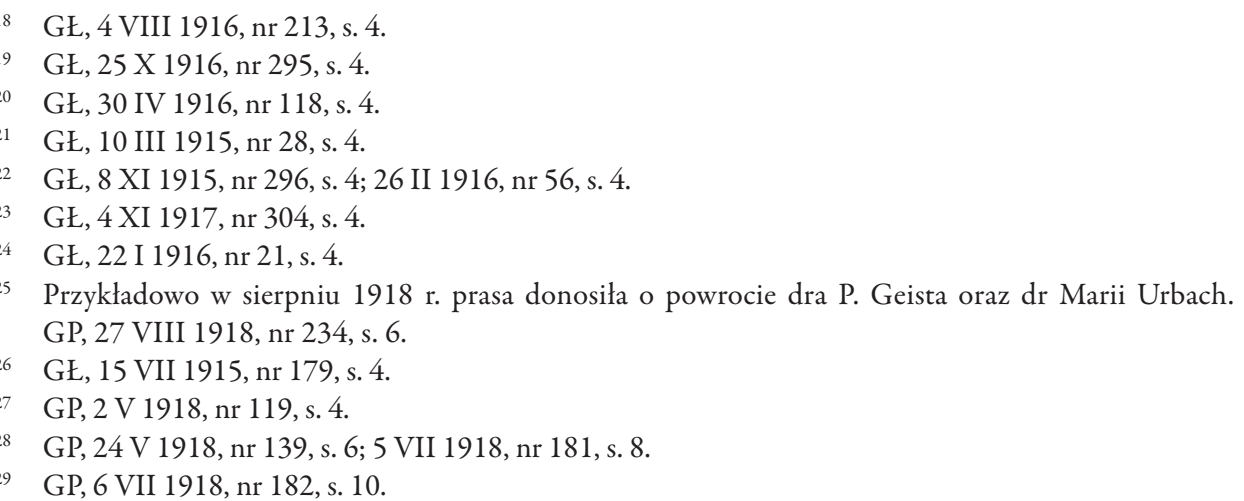


Omawiając świat łódzkiej stomatologii, warto zauważyć, że w przeciwieństwie do innych specjalności medycznych, dość znaczny procent łódzkich dentystów stanowiły kobiety $^{30}$. Tuż przed wybuchem wojny praktykę prowadziło tu około 20 pań $^{31}$.

Niewiele wiadomo na temat specyfików używanych przez ówczesnych łodzian do pielęgnowania higieny jamy ustnej. Niekiedy na łamach tódzkiej prasy pojawiały się reklamy, które zachwalały preparaty. Jednym z nich był „Odol”. Jak zapewniał na łamach anonsów prasowych producent płynu, preparat miał działać bakteriobójczo przez wiele godzin: „Odol wsysa się w dziurawe zęby i w błonę śluzową dziąseł, nasyca je do pewnego stopnia i ten to pozostający w ustach przeciwgnilny zapas działa właśnie godzinami" ${ }^{2}$.

Omawiając ówczesną tematykę dentystyczną, warto wspomnieć, że niektóre z klinik skupowały np. sztuczne szczęki. Oferowano skup zarówno szczęk całych, jak i uszkodzonych ${ }^{33}$. Instytut Techno-Dentystyczny przy ul. Krótkiej 9 (ob. Traugutta) prowadził natomiast skup „naturalnych szczęk z dobrym uzębieniem”. Te miały służyć podczas wykładów w szkole dla techników dentystycznych ${ }^{34}$. Na terenie miasta działały składy materiałów i instrumentów dentystycznych. Najpopularniejszy z nich działający pod szyldem „Progres” należał do Nathana Lewina i znajdował się przy ul. Piotrkowskiej $39^{35}$.

Większą dbałość o zdrowie zębów wykazywali przedstawiciele niemieckich władz okupacyjnych. Przy ul. Piotrkowskiej 86 znajdowała się specjalna przychodnia dla wojskowych i urzędników niemieckich ${ }^{36}$.

Omawiając dzieje ówczesnej stomatologii, warto wspomnieć o społeczności stomatologów łódzkich i grupujących ją organizacjach. Od $1904 \mathrm{r} \mathrm{r}^{37} \mathrm{w}$ Łodzi funkcjonowało Łódzkie Towarzystwo Odontologiczne (dalej: ŁTO) ${ }^{38}$. Siedziba organizacji w 1908 r. mieściła się przy ul. Piotrkowskiej 43. Towarzystwo miało m.in. własną bibliotekę ${ }^{39}$.

30 M. Sikorska-Kowalska, Czy Łódź w XIX wieku byta miastem kobiet?, „Studia z Historii Społeczno-Gospodarczej XIX i XX wieku" 2013, t. XI, s. 21, 24.

31 S. Borszyńska, Życie kobiet w Eodzi w latach 1908-1914 - wybrane aspekty, Łódź 2019, s. 45.

32 A. Stawiszyńska, Reklamy leków i parafarmaceutyków w gazetach tódzkich w czasie I wojny światowej, „Bez Recepty” 2014, nr 2, s. 23.

33 GE, 10 X 1915, nr 267, s. 4.

34 GE, 26 II 1916, nr 56, s. 6.

35 Ibidem, s. 4.

36 KDMilitargouverment Lodz, AP€, AmE, Wydział Techniczny, sygn. 23 455, k. 111.

37 Niektóre opracowania podają rok powstania 1905. J. Fijałek, J. Indulski, Opieka zdrowotna w Łodzi do roku 1945, Łódź 1990, s. 119; E. Więckowska, Lekarze jako grupa zawodowa w II Rzeczpospolitej, Warszawa 2004, s. 280.

38 Pierwszym prezesem organizacji był Teplicki, a jego zastępcą Lebiedińska. Funkcję sekretarza piastował wówczas J. Haberfeld. „Czasopismo Lekarskie” 1904, nr 7, s. 35; W. Jaworski, Prowincjonalne towarzystwa naukowe w Królestwie Polskim w drugiej potowie XIX wieku i na poczatku XX wieku, „Kwartalnik Historii Nauki i Techniki" 2006, t. LI, s. 196.

39 Kalendarz. Czas na rok przestępny 1908, Łódź 1907, s. 48. 
Jego prezesem był Jakub Haberfeld ${ }^{40}$, a zastępcą Rafał Litwin ${ }^{41}$. Niewiele wiadomo o działalności Towarzystwa w czasie wojny. Na początku tego konfliktu funkcję prezesa nadal piastował J. Haberfeld ${ }^{42}$, a siedziba mieściła się przy Nowym Rynku 6. W styczniu 1917 r. odbyło się zebranie, podczas którego prezes J. Haberfeld wygłosił referat podsumowujący 12 lat działalności organizacji, tj. za lata 1904-1917. Podkreślił w nim, że ŁTO było jednym z pierwszych na ziemiach polskich, a także scharakteryzował ożywioną działalność naukowo-dydaktyczną. Wspominał o współpracy z drem Dzierżawskim z Warszawy czy drem Mewem z Odessy. Na tym samym zebraniu zadecydowano o obniżeniu rocznej składki członkowskiej z 10 do 6 rb. Uczczono pamięć zmarłego w sierpniu 1916 r. członka ŁTO, Henryka Granasa ${ }^{43}$. Prawdopodobnie organizacja nie dysponowała własnym lokum, o czym świadczy to, że zebrania podsumowujące działalność odbywały się co roku w innych lokalach, np. w siedzibie Towarzystwa Nauczycieli Żydów przy ul. Mikołajewskiej (ob. Sienkiewicza) 35. Wśród zadań, jakie organizacja stawiała sobie w czasie wojny, była m.in. walka z „krzyczącymi reklamami”, a także zwalczanie osób wykonujących zawód dentysty bez uprawnień ${ }^{44}$. Problem ten dotyczył głównie techników dentystycznych, którzy przeprowadzali zabiegi przeznaczone wyłącznie dla dentystów. W marcu 1917 r. postanowiono nakazywać im zaprzestanie praktyk, a w przypadku, gdyby nie dostosowali się do tych żądań, przewidywano użycie środków przymusu $^{45}$. Przy Towarzystwie w czasie Wielkiej Wojny istniała biblioteka oraz kasa zapomogowa dla wdów i sierot. Organizacja ustaliła też minimalne stawki honorariów za poszczególne zabiegi ${ }^{46}$. Członkowie próbowali wpływać na poprawę jakości opieki zdrowotnej oferowanej przez miasto. Wiosną 1917 r. Towarzystwo Odontologiczne wysunęło pomysł zorganizowania bezpłatnego ambulatorium dla uczniów ${ }^{47}$.

40 J. Haberfeld (?-1927) - jeden z pierwszych łódzkich dentystów; publikował artykuły w czasopismach fachowych, a także wygłaszał odczyty dotyczące metod stosowanych w ówczesnej stomatologii (np. O wktadkach ztotych); właściciel gabinetu przy ul. Andrzeja (ob. A. Struga) 2; po jego śmierci ukonstytuował się Komitet dla uczczenia jego pamięci - w planach było ufundowanie stypendium dla studenta farmacji, uruchomienie przychodni oraz biblioteki jego imienia; ostatecznie zrealizowano jedynie ostatni pomysł - księgozbiór pochodził z prywatnej biblioteki J. Haberfelda podarowanego przez jego żonę oraz z biblioteki ŁTO i Łódzkiego Oddziału Związku Zawodowego Lekarzy-Dentystów w Państwie Polskim; na ścianie zawisł portret patrona. R. Litwin, Jakub Haberfeld (wspomnienie pośmiertne), „Echo Dentystyczne” 1927, R. II, nr 1-2, s. 16 oraz nr 3-4, s. 79; GŁ, 17 VIII 1914, nr 186, s. 2; Bibliografia polska 1901-1939, t. XI, red. G. Fedorowicz, M. Kaczyńska, I. Maziarz, Warszawa 2009, s. 11; I. Fijałek, J. Indulski, op. cit., s. 119.

41 Rafał Litwin (1872-1928) - lekarz dentysta, mąż dentystki Justyny z d. Sonnenberg. A. Kempa, M. Szukalak, Żydzi dawnej Łodzi. Stownik biograficzny, Łódź 2003, s. 74.

42 Wiceprezesem był Szewes, sekretarzem S. Lipowski. Czas. Kalendarz na rok 1914, cz. 1, Łódź 1913, s. 80.

43 GE, 19 I 1917, nr 17, s. 4; NKE, 29 VIII 1916, nr 236, s. 3.

44 GE, 30 III 1917, nr 87, s. 3.

45 Ibidem.

46 GE, 19 I 1917, nr 17, s. 4.

47 GE, 30 III 1917, nr 87, s. 3. 
Projekt ten został przekazany Sekcji Szkolnej Magistratu z prośbą o wsparcie finansowe $^{48}$. Siedziba organizacji w 1918 r. mieściła się przy ul. Południowej (ob. Rewolucji 1905 r.) $3^{49}$. W skład organizacji nie wchodzili technicy dentystyczni ${ }^{50}$. Niewiele wiadomo o pozamedycznych aspektach działalności organizacji. Wśród nielicznych informacji na tenże temat warto wymienić to, że członkowie Towarzystwa brali udział w obchodach 125 rocznicy uchwalenia Konstytucji 3 maja, maszerując w okolicznościowym pochodzie ${ }^{51}$.

Kolejną organizacją zrzeszającą łódzkich dentystów było powstałe w 1907 r. na skutek rozłamu we wspomnianej organizacji Drugie Towarzystwo Lekarzy-Dentystów miasta Łodzi ${ }^{52}$ z siedzibą przy ul. Głównej (ob. Piłsudskiego) 50. W 1908 r. na jego czele stał Adolf Żadziewicz ${ }^{53}$. Natomiast w 1914 r. prezesem był A. Strusiński, jego zastępcą L. Guenther, a sekretarzem A. Żadziewicz. Siedziba mieściła się przy ul. Piotrkowskiej $86^{54}$. Brakuje jednak informacji na temat działalności organizacji w dobie wojny.

Niektórzy z dentystów angażowali się indywidualnie w sprawy społeczne. W 1917 r. Michał Salzwasser ubiegał się o mandat członka Rady Miejskiej w Zgierzu ${ }^{55}$. Gustaw Klukow był członkiem zorganizowanej w listopadzie 1914 r. Milicji Telefonicznej ${ }^{56}$, a w wyborach kurialnych przeprowadzonych w 1917 r. został radnym miejskim ${ }^{57}$. Nie była to zbyt wielka reprezentacja we władzach miejskich, porównując chociażby z zaangażowaniem społecznym innych grup zawodowych legitymujących się wyższym wykształceniem, np. miejscowych aptekarzy ${ }^{58}$.

8 GE, 5 XII 1917, nr 335, s. 3.

49 Łódzkie Towarzystwo Odontologiczne, APŁ, AmE, Wydział Statystyczny, sygn. 23 581, k. 61.

50 NKE, 31 III 1917, nr 88, s. 2.

51 125-lecie Konstytucji na Ziemiach Piotrkowskiej, Sieradzkiej i Kaliskiej, Łódź 1917, s. 9.

52 Niektóre opracowania podają nazwę Stowarzyszenie Dentystów w Łodzi, Towarzystwo Lekarzy Dentystów lub Towarzystwo Dentystów miasta Łodzi. W. Jaworski, op. cit., s. 197; M.M. Żydowo, Dzieje nauczania medycyny na ziemiach polskich, Warszawa 2001, s. 123.

53 Kalendarz. Czas na rok..., s. 49.

54 Czas. Kalendarz 1914..., s. 80.

55 „Gazeta Zgierska”, 6 I 1917, nr 2, s. 3.

56 Milicja dla Ochrony telefonów i telegrafów - powołana przez rosyjską komendanturę wojskową w związku z przypisywaniem Żydom niszczenia linii telefonicznych. W jej skład wchodzili funkcjonariusze narodowości żydowskiej. Jej zadaniem była całodobowa ochrona szlaku linii telefonicznych. W jej pracę zaangażowana była Gmina Wyznaniowa. Funkcjonariusze nosili na ramieniu opaski z literą „T”. A. Stawiszyńska, Dziatalność Milicji Obywatelskiej w Eodzi (sierpień 1914 - lipiec 1915), „Acta Universitatis Lodziensis. Folia Historica” 2015, z. 94, s. 112; F. Schuster, Eódzcy Żydzi w okresie I wojny światowej-zapomniana historia?, [w:] Łódź i region w czasie I wojny światowej. Między wielką historia a codziennością, red. K. Radziszewska, P. Zawilski, Łódź 2011, s. 55.

57 Relacja z zebrania członków Milicji Telefonicznej, APŁ, Łódzka Gmina Wyznaniowa Żydowska, sygn. 19, k. 6; A. Stawiszyńska, Łódź w latach..., s. 448, 674.

58 A. Stawiszyńska, Świat tódzkiej farmacji w latach I wojny światowej, „Farmacja Polska” 2013, nr 6, s. $708-712$. 
Niekiedy dentyści mogli liczyć na przywileje ze strony miasta. Tak było w 1917 r., gdy w mieście odczuwano $\mathrm{m}$. in. poważne niedobory opału, dentyści otrzymywali np. specjalne przydziały węgla od Wydziału Opałowego Magistratu ${ }^{59}$.

Spośród łódzkich stomatologów zdarzały się osoby wzbudzające kontrowersje ze względu na swoje wcześniejsze związki z władzami carskimi. W czasach okupacji niemieckiej na łamach przychylnej Niemcom „Gazety Łódzkiej” ukazał się artykuł opisujący postać jednego z łódzkich dentystów A. Żadziewicza ${ }^{60}$. Tekst szczególną uwagę zwracał na zażyłość między stomatologiem a władzami carskimi. Podkreślano, że szkoła dentystyczna, jaką prowadził przy ul. Piotrkowskiej 86, zawdzięczała swój rozwój układom właściciela z rosyjską ochraną, której miał świadczyć bezpłatne usługi medyczne. Szczególnie zażyłe miały być jego relacje z szefem ochrany Leontowiczem ${ }^{61}$. Żadziewicz miał też bywać z wizytami u gubernatora piotrkowskiego Michaiła Jaczewskiego. Przyjaźnił się też z inspektorem piotrkowskiego urzędu lekarskiego, drem Tieplaszynem. Stomatolog opuścił miasto tuż po ewakuacji administracji carskiej na początku wojny. Osiadł w Witebsku, gdzie uruchomił szkołę dentystyczną ${ }^{62}$.

Młodzi łodzianie pragnący kształcić się na stomatologów nie mieli możliwości podjęcia edukacji na miejscu. W pierwszych tygodniach wojny, na łamach miejscowej prasy, podobnie jak przed wojną, pojawiały się anonse uczelni z innych, głównie rosyjskich miast. Jedną z takich szkół była Szkoła Dentystyczna dra I.A. Paszutina i W.D. Jerfemowa z Sankt Petersburga ${ }^{63}$. Podobną naukę oferowała Pierwsza Warszawska Lekarsko-Dentystyczna Szkoła L. Szymańskiego ${ }^{64}$.

Kwestie związane z dbałością o zęby niewątpliwie nie należały do najważniejszych zagadnień medycyny łódzkiej okresu Wielkiej Wojny. Ustępowały one bardziej realnym z punktu widzenia ówczesnych łodzian zagrożeniom, takim jak choroby zakaźne

59 GP, 20 X 1917, nr 290, s. 3.

60 Adolf Żadziewicz lub Żadiweicz (ur. 1868 Prużany, zm. 1936 Łódź?) - absolwent Szkoły Lekarsko-Dentystycznej w Warszawie; w 1899 r. przybył do Płocka, gdzie praktykował około roku, po czym przeniósł się do Łodzi, gdzie pracował jako dentysta szkolny w gimnazjum męskim, a także prowadził prywatną praktykę przy ul. Piotrkowskiej 31, a następnie Piotrkowskiej 120. W 1903 r. na Wystawie Dydaktyczno-Higienicznej w Warszawie przedstawił wyniki badań nad uzębieniem młodzieży szkolnej opracowanej na podstawie około 4000 przebadanych uczniów. W 1909 r. skonstruował sztuczny nos połączony z zatykadłem podniebiennym i sztucznymi szczękami; w 1907 r. otrzymał złoty medal na Wystawie Przyrodniczo-Lekarskiej we Lwowie; angażował się w działalność Towarzystwa Opieki nad Dziećmi. W. Berner, J. Supady, Dziatalność lekarsko-spoteczna na rzecz zdrowia publicznego $w$ Eodzi w latach 1870-1914, Łódź 2001, s. 210; B. Papierska, Ptoccy stomatolodzy w latach 1883-1939, „Notatki Płockie” 1974, t. XIX, s. 17; „Orędownik”, 31 VIII 1936, nr 302, s. 3; „Rozwój”, 27 VII 1907, nr 165, s. 4; 17 II 1911, nr 39, s. 2.

61 Pogłoski głosiły, że pozwolenie na prowadzenie własnej szkoły w Łodzi otrzymał w zamian za składanie donosów w czasie rewolucji 1905 r. „Orędownik”, 31 VIII 1936, nr 302, s. 3.

62 GE, 1 VIII 1917, nr 209, s. 3.

63 „Rozwój”, 3 IX 1914, nr 200, s. 4.

64 „Rozwój”, 14 VIII 1914, nr 184, s. 4. 
zbierające wówczas śmiertelne żniwo. Na wspomniany stan rzeczy wpływała także zapewne niska świadomość łodzian dotycząca zdrowia. Należy przypuszczać, że dostęp do leczenia zębów miały wówczas niemal wyłącznie osoby zamożne.

\section{Bibliografia (Bibliography)}

\section{Źródła archiwalne}

Archiwum Państwowe w Łodzi [APŁ]

Akta miasta Łodzi [AmŁ]

Rada Miejska, sygn. 12109.

Wydział Prezydialny, sygn. 13515.

Wydział Statystyczny, sygn. 23581.

Wydział Techniczny, sygn. 23455.

Łódzka Gmina Wyznaniowa Żydowska, sygn. 19.

\section{Prasa}

„Gazeta Łódzka” 1914-1917.

„Gazeta Zgierska” 1917.

„Godzina Polski” 1916-1918.

„Nowy Kurier Łódzki” 1916-1918.

„Orędownik” 1936.

„Rozwój” 1907, 1911, 1914.

\section{Opracowania}

125-lecie Konstytucji na Ziemiach Piotrkowskiej, Sieradzkiej i Kaliskiej, Łódź 1917.

Berner W., Supady J., Dziatalność lekarsko-spoteczna na rzecz zdrowia publicznego w Eodzi w latach 1870-1914, Łódź 2001.

Bibliografia polska 1901-1939, t. XI, red. G. Fedorowicz, M. Kaczyńska, I. Maziarz, Warszawa 2009.

Borszyńska S., Życie kobiet w Łodzi w latach 1908-1914, Łódź 2019.

Czas. Kalendarz na rok 1914, cz. 1, Łódź 1913.

Fijałek J., Indulski J., Opieka zdrowotna w Łodzi do roku 1945, Łódź 1990.

Fijałek J., Supady J., Gruźlica ptuc Łodzi od schytku XIX do 1918 r. Z dziejów walki z chorobą, Łódź 2002.

Jaworski W., Prowincjonalne towarzystwa naukowe $w$ Królestwie Polskim $w$ drugiej potowie XIX wieku i na poczatku XX wieku, „Kwartalnik Historii Nauki i Techniki” 2006, t. LI, s. 195-201. 
Kalendarz. Czas na rok przestępny 1908, Łódź 1907.

Kempa A., Szukalak M., Żydzi dawnej Łodzi. Stownik biograficzny, Łódź 2003.

Kulesza A., Zapobieganie i zwalczanie chorób zakaźnych w Eodzi w latach 1915-1918 w świetle regulacji normatywnych niemieckich cywilnych wtadz okupacyjnych, „Studia z Dziejów Państwa i Prawa Polskiego" 2007, t. X, s. 249-264.

Litwin R., Jakub Haberfeld (wspomnienie pośmiertne), „Echo Dentystyczne” 1927, nr 1-2, s. 15-16.

Margolis A., Gruźlica w Eodzi. Studium epidemiologiczno-statystyczne, Łódź 1932.

Papierska B., Ptoccy stomatolodzy w latach 1883-1939, „Notatki Płockie” 1974, t. XIX, s. 16-19.

Pawłowska-Dąbrowska M., Sprawozdanie z czynności szpitala miejskiego dla lekko-gruźliczych w Chojnach pod Eodzia za lata 1916-1917, „Zdrowie. Organ Warszawskiego Towarzystwa Higienicznego" 1918, t. VII, s. 201-202.

Schuster F., Łódzcy Żydzi w okresie I wojny światowej - zapomniana historia?, [w:] Eódź i region w czasie I wojny światowej. Między wielka historia a codziennością, red. K. Radziszewska, P. Zawilski, Łódź 2011, s. 49-68.

Sikorska-Kowalska M., Czy Łódź w XIX wieku byta miastem kobiet?, „Studia z Historii Społeczno-Gospodarczej XIX i XX wieku" 2013, t. XI, s. 19-27.

Sosnowska J., Opieka nad dziećmi w Eodzi w latach I wojny światowej, Łódź 2017.

Stawiszyńska A., Dziatalność Milicji Obywatelskiej w Łodzi (sierpień 1914 - lipiec 1915), „Acta Universitatis Lodziensis. Folia Historica” 2015, z. 94, s. 109-132.

Stawiszyńska A., Łódź w latach I wojny światowej, Oświęcim 2016.

Stawiszyńska A., Reklamy leków i parafarmaceutyków w gazetach tódzkich w czasie I wojny światowej, „Bez Recepty” 2014, nr 2, s. 22-25.

Stawiszyńska A., Świat tódzkiej farmacji w latach I wojny światowej, „Farmacja Polska” 2013, nr 6, s. 707-713.

Supady J., Walka z cholera w Eodzi na przetomie XIX i XX wieku, „Polski Tygodnik Lekarski” 1978, t. XXXIII, nr 2, s. 75-76.

Więckowska E., Lekarze jako grupa zawodowa w II Rzeczpospolitej, Warszawa 2004.

Żydowo M.M., Dzieje nauczania medycyny na ziemiach polskich, Warszawa 2001.

\section{Notka o autorce:}

dr Aneta Stawiszyńska - absolwentka historii na Wydziale Filozoficzno-Historycznym Uniwersytetu Łódzkiego.

Zainteresowania badawcze: historia społeczna I wojny światowej, historia Łodzi, biografistyka.

\anetas83@wp.pl 